\title{
announcements/call for papers
}

\section{TH AMS ANNUAL MEETING_-Diamond Anniversary" 15-20 JANUARY 1995, DALLAS, TEXAS}

The 75th AMS Annual Meeting - "Diamond Anniversary" will be held 15-20 January 1995 at the Loews Anatole Hotel, Dallas, Texas. Several conferences, a large commercial exhibit program, a combined book exhibit, and a "Diamond Anniversary" banquet are being planned. "Calendar of Meetings" includes a listing of those conferences presently scheduled. The theme of the 75th AMS Annual Meeting will be the retrospective and future views of the atmospheric and related oceanic and hydrological sciences. It is also time to give special acknowledgment to the growth of professional applications within the society. Attention will be given at the meeting to new directions for the meteorological sciences which are more interdisciplinary and which focus on further scientific understanding and service to national and world communities. (8/93; r11/93)

Symposium on Imperatives for Atmospheric Sciences Entering the 21st Century, 17 January 1995, Dallas, Texas

A session on Imperatives for Atmospheric Sciences Entering the 21st Century will be held on 17 January 1995 as part of the AMS 75th Annual Meeting-"Diamond Anniversary" at the Loews Anatole Hotel, Dallas, Texas. The National Research Council Board on Atmospheric Sciences and Climate, in collaboration with the American Meteorological Society, will give a mid-term report of an assessment of the opportunities, challenges, and imperatives for the atmospheric sciences entering the 21 st century. The Board, in presenting its findings to date, seeks suggestions concerning the major scientific problems, research objectives, experimental programs, and policy issues that should be considered in setting future directions for atmospheric sciences.

The session is being arranged by Prof. John A. Dutton, The Pennsylvania State University, Dept. of Meteorology, 503 Walker Building, University Park, PA 16802 (tel: 814865-1534). Following presentations scheduled for Tuesday, 17 January, a special session to hear audience reactions and suggestions and to debate issues is scheduled for that evening. Refreshments will be provided for the evening discussion. The 75th Annual Meeting program was published in the October issue of the Bulletin. $(6 / 94 ;$ r10/94)

\section{Symposium on History of the Atmospheric Sciences,} 18 January 1995, Dallas, Texas

A history symposium is scheduled for Wednesday, 18 January 1995 at the Loews Anatole Hotel, Dallas, Texas, as an important part of the 75th AMS Annual Meeting-"Diamond Anniversary." Invited speakers will address the following topics: Evolution of Atmospheric Dynamics (Edward N. Lorenz); Evolution of Atmospheric Observations (Robert J. Serafin); Origin and Rise of Numerical Weather Prediction
(George P. Cressman); Evolution of Hurricane Forecasting (Mark De Maria); Emergence of Atmospheric Chemistry (Ralph J. Cicerone); Evolution of Climatology from Descriptive to Analytic (John E. Kutzbach); 20th Century Arctic Research (Norbert Untersteiner); Ocean-Atmosphere Interactions from 1920 to 1995 (John M. Wallace). The symposium is being organized by Professor Robert G. Fleagle, Dept. of Atmospheric Sciences, Univ. of Washington, Seattle, WA (tel: 206-543-4594; fax: 206-543-0308). The 75th Annual Meeting program was published in the October issue of the Bulletin. $(6 / 94 ; \mathrm{r} 10 / 94)$

Short Course on Spatial Statistics: Methods and Applications, 15 January 1995, Dallas, Texas

A Short Course on Spatial Statistics: Methods and Applications is being organized by the AMS Committee on Probability and Statistics, and will be held 15 January 1995 at the Loews Anatole Hotel, Dallas, Texas, as part of the 75th AMS Annual Meeting -"Diamond Anniversary." This course will emphasize spatial analysis techniques particularly useful to researchers in the disciplines of applied climatology, hydrology, weather analysis and forecasting, aviation weather, and global change studies, but will be of interest to many other conference attendees as well.

For further information, please contact Timothy J. Brown, Chairperson, Probability and Statistics Committee, University of Colorado, CIRES, Campus Box 449, Boulder, CO 80309 (tel: 303-492-8986; fax: 303-497-7013; internet: tjb@noaacdc.colorado.edu). The 75th Annual Meeting program was published in the October issue of the Bulletin. (6/ 94; r10/94)

Short Course on Numerical Weather Prediction (NWP) and on GOES-8 Products for the Broadcast and Private Sector Meteorologist, 15 January 1995, Dallas, Texas

The AMS Board of Broadcast Meteorology has organized a Short Course on Numerical Weather Prediction (NWP) and on GOES-8 Products for the Broadcast and Private Sector Meteorologist, to be held Sunday, 15 January 1995, at the Loews Anatole Hotel, Dallas, Texas. The course will address several issues including advances in numerical weather prediction, the new series of Geostationary Operational Environmental Satellites (GOES-8), as well as new model advancements at the National Meteorological Center. The course will be of particular interest to forecasters-especially to broadcast meteorologists and those forecasters in the private sector. A schedule of course speakers will appear in the Industrial Meteorology Update Newsletter. The short course chairperson is Troy Kimmel. For further information, contact the course organizer, Allan Eustis (tel: 301-713-0258; fax: 301-713-0662). The 75th Annual Meeting program was published in the October issue of the Bulletin. (3/94; r4/94; r6/94; r10/94) 
24th Conference on Broadcast Meteorology, 15-18 January 1995, Dallas, Texas

The 24th AMS Conference on Broadcast Meteorology, organized by the AMS Board of Broadcast Meteorology, will be held 15-18 January 1995 at the Loews Anatole Hotel, Dallas, Texas, as part of the 75th AMS Annual Meeting"Diamond Anniversary." In order to facilitate this very important conference, a 1994 summer broadcast conference was not held.

This conference will focus on the role that broadcast meteorologists play in the dissemination of weather information, both in severe and non-severe weather situations; in addition, the role of "educator" in weather awareness and atmospheric science issues will be addressed. Issues, as they regard technological advances in meteorology and particularly, broadcast meteorology, will be examined. Forecast issues, as they relate to broadcast meteorologists, will be addressed as well. The deadline for abstracts has passed. The program cochairpersons for this conference are: Todd Glickman, Fred Gadomski, and Dana Tyler. For further information, contact Todd Glickman, AMS, 45 Beacon Street, Boston, MA 02108 (tel: 617-227-2426 ext. 213; fax 617-7428718 ). The 75 th Annual Meeting program was published in the October issue of the Bulletin. Details of this conference were published in the December 1993-July 1994 issues of the Bulletin.

14th Conference on Weather Analysis and Forecasting, 15-20 January 1995, Dallas, Texas

The 14th AMS Conference on Weather Analysis and Forecasting, organized by the AMS Committee on Weather Analysis and Forecasting, will be held in conjunction with the AMS 75th Annual Meeting-"Diamond Anniversary" 15-20 January 1995 at the Loews Anatole Hotel, Dallas, Texas.

The deadline for abstracts has passed. Details of this conference were published in the November 1993-July 1994 issues of the Bulletin. A preprint volume will be distributed to registrants at the conference. For further information, contact either cochairperson, Gary Carter, NOAA/NWS, Eastern Region, Scientific Services Division, 630 Johnson Avenue, Bohemia, NY 11716 (tel: 516-244-0131; fax: 516244-0167) or Lt. Col. Tim Crum, WSR-88D Operational Support Facility, 1200 Westheimer Drive, Norman, OK 73069 (tel: 405-366-6530 x252; fax: 405-366-6550). The 75th Annual Meeting program was published in the October issue of the Bulletin. (11/93; r3/94; r6/94; r8/94; r9/94; r10/94)

11th International Conference on Interactive Information and Processing Systems (IIPS) for Meteorology, Oceanography, and Hydrology, 15-20 January, 1995, Dallas, Texas

The 11th International Conference on IIPS, sponsored by the American Meteorological Society will be held 15-20 January 1995 at the Loews Anatole Hotel, Dallas, Texas, as part of the 75th AMS Annual Meeting-"Diamond Anniversary." The 11th IIPS Conference will be cosponsored by the World Meteorological Organization (WMO), the Joint Oceanographic Institutions (JOI), the American Water Resources Association (AWRA), and the Association of American Geographers (AAG).
This conference brings together the government and private sectors, both international and national, and those who supply or use data and information systems and technology. The conference will include exhibits and demonstrations which continue to be popular and help to illustrate the practicality of using off-the-shelf, demonstrated marketable systems and software tailored to meet the needs of meteorology, oceanography, and hydrology. Potential exhibitors should contact Yale Schiffman, Exhibits Manager, American Meteorological Society, 1701 K Street., N.W., Suite 300, Washington, DC 20006-1509 (tel: 202-466-6070; fax: 202466-6073).

The deadline for abstracts has passed. Details of the conference were published in the December 1993-July 1994 issues of the Bulletin. Registrants will receive a preprint volume at the conference. For further information, contact Dr. Robert F. Brammer, 55 Walkers Brook Drive, Reading, MA 01867 (tel: 617-942-2000; fax: 617-942-7100). The 75th Annual Meeting program was published in the October issue of the Bulletin. (12/93; r6/94; r7/94; r8/94; r9/ 94; r10/94)

\section{Ninth Conference on Applied Climatology, 15-20 Janu- ary 1995, Dallas, Texas}

The AMS Ninth Conference on Applied Climatology, will be held as part of the 75th AMS Annual Meeting_-Diamond Anniversary," 15-20 January 1995 at the Loews Anatole Hotel in Dallas, Texas. The conference is being organized by the AMS Committee on Applied Climatology.

The deadline for abstracts has passed. Details of this conference were published in the August 1993-July 1994 issues of the Bulletin. Registrants will receive a preprint volume at the conference. For further information, contact Dr. Ellen J. Cooter, NOAA/ARL, Research Triangle Park, NC 27711, (tel: 919-541-1334; fax: 919-541-3615; e-mail: cooterej@climate.rtpnc.epa.gov). The 75th Annual Meeting program was published in the October issue of the Bulletin. (8/93; r12/93; r8/94; r9/94; r10/94)

\section{Sixth Symposium on Global Change Studies, 15-20 January 1995, Dallas Texas}

The AMS Sixth Symposium on Global Change Studies, will be held 15-20 January 1995, at the Loews Anatole Hotel in Dallas, Texas, as a part of the 75th AMS Annual Meeting-"Diamond Anniversary." The primary theme of the symposium will be the elements of an end-to-end assessment of global change.

The deadline for abstracts has passed. Details of this symposium were published in the December 1993-July 1994 issues of the Bulletin. Registrants will receive a preprint volume at the conference. For further information about the symposium, contact Eric J. Barron, Earth System Science Center, 248 Deike Bldg., Pennsylvania State University, University Park, PA 16802 (tel: 814-865-1619; fax: 814-865-3191; Omnet: E.Barron; internet: eric@essc.psu.edu). The 75th Annual Meeting program was published in the October issue of the Bulletin. (12/93; r6/ 94; r8/94; r9/94; r10/94) 
Sixth Conference on Aviation Weather Systems, 15-20 January 1995, Dallas, Texas

The AMS Sixth Conference on Aviation Weather Systems, organized by the AMS Committee on Aviation, Range and Aerospace Meteorology, will be held 15-20 January 1995, at the Loews Anatole Hotel in Dallas, Texas, as a part of the 75th AMS Annual Meeting - "Diamond Anniversary." The World Meteorological Organization (WMO), and the International Civil Aviation Organization (ICAO), and the American Institute of Aeronautics and Astronautics (AIAA) Atmospheric Environment Technical Committee (AETC) will be cosponsors of this meeting.

The deadline for abstracts has passed. Details of this symposium were published in the December 1993-July 1994 issues of the Bulletin. Registrants will receive a preprint volume at the conference. For further information, contact Ms. Denise Vandeloo, Aviation Conference Program Coordinator, National Severe Storms Forecast Center, Rm. 1728 Federal Bldg., 601 East 12th St., Kansas City, MO 64106 (tel: 816426-5922 or fax: 816-426-3453), or either of the Program Cochairpersons, James H. Henderson, National Severe Storms Forecast Center, Rm. 1728 Federal Bldg., 601 East 12th St., Kansas City, MO 64106 (tel: 816-426-5922; e-mail: JHENDERSON@NSSFC.PO.KC.NOAA.GOV); Dr. Lynn A. Sherretz, Aviation Division, Forecast System Laboratory, Mail Code R/E/FS5, 325 Broadway, Boulder, CO 80303-3328 (tel: 303-497-5580; e-mail: SHERRETZ@FSL.NOAA.GOV). The 75th Annual Meeting program was published in the October issue of the Bulletin. (12/93; r6/94; r8/94; r9/94; r10/94)

Fourth Conference on Polar Meteorology and Oceanography, 15-20 January 1995, Dallas, Texas

The AMS Fourth Conference on Polar Meteorology and Oceanography, will be held 15-20 January 1995, at the Loews Anatole Hotel in Dallas, Texas, as a part of the 75th AMS Annual Meeting-"Diamond Anniversary." The conference is being organized by the AMS Committee on Polar Meteorology and Oceanography.

The deadline for abstracts has passed. Registrants will receive a preprint volume at the conference. For further information, contact Prof. Judith A. Curry, Program in Atmospheric and Oceanic Sciences, Campus Box 311, University of Colorado, Boulder, CO 80309 (tel: 303-492-5733; fax: 303-492-2825; e-mail: curryja @ cloud.colorado.edu). The 75th Annual Meeting program was published in the October issue of the Bulletin. (10/93; r12/93; r6/94; r9/94; r10/94)

\section{Fourth Symposium on Education, 15-18 January 1995, Dallas, Texas}

The Fourth AMS Symposium on Education, will be held 15-18 January 1995, at the Loews Anatole Hotel in Dallas, Texas, as a part of the 75th AMS Annual Meeting"Diamond Anniversary." The symposium is organized by the AMS Board on School and Popular Meteorological and Oceanographic Education and the AMS Board on Meteorological and Oceanographic Education in Universities. The theme of the symposium will be "Opening the Door to the Future: Education in the Classroom and Beyond."

The deadline for abstracts has passed. Details of this symposium were published in the August 1993-July 1994

\section{Call for Videos}

A solicitation is being made for video contributions to the "History of Broadcast Meteorology" session. We would also like to receive video coverage of any meteorological, oceanographic, or hydrologic phenomena of historic significance or importance that would be of general interest to the attendees at the 75th AMS Annual Meeting. Videos received under this call will be shown at scheduled times throughout the annual meeting. These videos will be listed in the annual meeting program along with scheduled viewing times in the video theater. Contributions can be made on Beta or $3 / 4$ " format to Troy Kimmel, 6512 Sans Souci Cove, Austin, TX 787595163 (tel: 512-335-6472). (12/93; r1/94; r4/94; r6/94; r8/94; r9/94; r10/94)

issues of the Bulletin. A preprint volume will be distributed to registrants at the conference. For further information, contact David R. Smith, (K-12 Topics and joint session with broadcast meteorologists) Oceanography Department, U.S. Naval Academy, 572 Holloway Road, Annapolis, MD 21402 (fax: 410-293-2137) or Lisa Bastiaans (college/university topics and joint session with IIPS), Nassau Community College, Physical Sciences Department, Garden City, NY 11530 (fax: 516-572-7846). The 75th Annual Meeting program was published in the October issue of the Bulletin. (8/ 93; r12/93; r3/94; 6/94; 8/94; r9/94; r10/94)

\section{Conference on Cloud Physics, 15-20 January 1995, Dallas, Texas}

The AMS Conference on Cloud Physics, organized by the AMS Committee on Cloud Physics, will be held as part of the 75th AMS Annual Meeting-"Diamond Anniversary" 15-20 January 1995 at the Loews Anatole Hotel in Dallas, Texas.

The deadline for abstracts has passed. A preprint volume will be distributed to registrants at the conference. For further information, contact Harry T. Ochs, Illinois State Water Survey, 2204 Griffith Drive, Champaign, IL 61820 (tel: 217-333-4964; fax: 217-333-6540). The 75th Annual Meeting program was published in the October issue of the Bulletin. (8/93; r12/93; r6/94; r9/94; r10/94)

\section{Conference on Hydrology, 15-20 January 1995, Dallas, Texas}

The AMS Conference on Hydrology, organized by the AMS Committee on Hydrology, will be held as part of the 75th AMS Annual Meeting-"Diamond Anniversary" 15-20 January 1995 at the Loews Anatole Hotel in Dallas, Texas. The central theme of the conference is on the influence of hydrological processes within the soil and the biosphere on the variability of weather and climate. Correspondingly, studies on the role of atmospheric and hydrologic processes working at local to regional spatial scales and event to climatic temporal scales are included. 
The deadline for abstracts has passed. Details of this conference were published in the December 1993-July 1994 issues of the Bulletin. A preprint volume will be distributed to registrants at the conference. For further information, please contact either cochairperson: William P. Kustas, USDA-ARS, Hydrology Lab., Bldg. 007, BARC-WEST, Beltsville, MD 20705 (tel: 301-504-8498; fax: 301-5048931; e-mail: bkustas@hydrolab.arsusda.gov) or Dara Entekhabi, Dept. of Civil \& Environmental Engineering, Bldg. 48-331, Massachusetts Institute of Technology, Cambridge, MA 02139 (tel: 617-253-9698; fax: 617-258-8850; e-mail: dara@alborz.mit.edu). The 75th Annual Meeting program was published in the October issue of the Bulletin. (12/ 93; r6/94; r8/94; r9/94; r10/94)

\section{Symposium on the Regulation of Sea Surface Tempera- tures and Warming of the Tropical Ocean-Atmosphere System 15-20 January 1995, Dallas, Texas}

A Symposium on the Regulation of Sea Surface Temperatures and Warming of the Tropical Ocean-Atmosphere System arranged by the Scientific Steering Committee of the CEPEX Project and organized by J. P. Kuettner (NCAR), V. Ramanathan (Scripps), and W. M. Washington (NCAR) is being planned as part of the AMS 75th Annual Meeting"Diamond Anniversary" 15-20 January 1995 at the Loews Anatole Hotel, Dallas, Texas.

This symposium will focus on interdisciplinary topics dealing with the long term changes of the coupled ocean atmosphere system in the tropics. The deadline for abstracts has passed. Details of this symposium were published in the March-July 1994 issues of the Bulletin. For further information contact Dr. V. Ramanathan, Scripps Institution of Oceanography, 9500 Gilman Drive, 0221, La Jolla, CA 92093-0221, (tel: 619-534-8815; fax: 619-5344922; e-mail: (Internet) ram @ uscsd.edu). The 75th Annual Meeting program was published in the October issue of the Bulletin. (3/94; r6/94; r8/94; r10/94)

Fifth IEEE Working Conference on Current Measurement, 7-9 February 1995, St. Petersburg, Florida

The Fifth IEEE Working Conference on Current Measurement, will be held 7-9 February 1995 in St. Petersburg, Florida. The meeting is sponsored by the Current Measurement Technology Committee of the IEEE Oceanic Engineering Society; the American Meteorological Society is a cooperating organization. The conference theme is "Upper Ocean, Boundary Layer, Moving Platform, and Non-Invasive Current Measurements." Session topics include: doppler current sensors, acoustic transmission current sensors, fluxmeters, remote current sensors, boundary layer sensors; and moving platform sensors.

For further information, contact Albert J. Williams III, Technical Program Coordinator, Woods Hole Oceanographic Institution, Bigelow 110, Woods Hole, MA 02543, tel: 508-457-2000, ext. 2725, OMNET: a.williams, EMAIL: awilliams@ cliff.whoi.edu. (8/94; 9/94, r11/94)

Tropical Mesoscale Meteorology Symposium, 11 February 1995, Honolulu, Hawaii

The Tropical Mesoscale Meteorology Symposium will be held 11 February 1995 in Honolulu, Hawaii. The symposium is sponsored by the Cooperative Program for Operational Meteorology, Education and Training (COMET) and hosted by the University of Hawaii. COMET is a UCAR program funded by NOAA under Cooperative Agreement NA37WD0018-01. The American Meteorological Society is a cooperating organization.

The objective of the symposium is to give Pacific Region meteorologists and others interested in tropical meteorology an opportunity to share information on issues and advances in the area. The theme of this symposium is "A New View of Weather in the Tropical Pacific: From the Mesoscale," COMET intends to facilitate the integration of the new tools of the NWS modernization into operational forecasting in the Pacific Region.

The deadline for abstracts has passed. Registrations should be sent to Victoria C. Johnson, COMET, P.O. Box 3000, Boulder, CO 80307, (tel: 303-407-8361; fax: 303-4978491; e-mail: vjohnson @ comet.ucar.edu) by 1 December 1994. A preprint volume of the abstracts will be available at the symposium. (8/94; r10/94)

\section{Biomass Burning and Global Change Conference, 13- 17 March 1995, Williamsburg, VA}

The Biomass Burning and Global Change Conference will be held 13-17 March 1995 in Williamsburg, VA. The American Meteorological Society is a cooperating organization. The conference will consist of 10 half-day oral sessions featuring tutorials, review talks, and contributed talks. Public lectures in the evening are also planned.

The aim of this Chapman Conference is to assess the role and importance of biomass burning as a process for global change. The conference will consider the impact of gaseous and particulate emissions form biomass burning on atmospheric chemistry, on the biogeochemical cycling of elements, and on climate.

The deadline for abstracts has passed. Details of this conference were published in the August-November 1994 issues of the Bulletin. For further information please contact AGU Meetings Department, Biomass Burning, 2000 Florida Ave., N.W., Washington, DC 20009, tel: 202-462-6900; fax: 202-328-0566; e-mail: meetinginfo@kosmos.agu.org.

Preregistration deadline is 10 February 1995 . Funding for travel support is being requested from several agencies. If funding is received, a limited amount of travel support will be available. Applications for travel support can be obtained from the American Geophysical Union at the address listed above. (8/94; r12/94)

International Symposium on Assimilation of Observations in Meteorology and Oceanography, 13-17 March 1995, Tokyo, Japan

The International Symposium on Assimilation of Observations in Meteorology and Oceanography will be held 1317 March 1995 in Tokyo, Japan and is sponsored by the World Meteorological Organization (WMO) and cosponsored by the American Meteorological Society (AMS); it will be hosted by the Japan Meteorological Agency (JMA).

The symposium will consist of two parts: i) a two-day intensive course, at the senior undergraduate-to-beginning 
graduate level of a U.S. university, and ii) a three-day research conference. The intensive course will be held Monday-Tuesday, 13-14 March, and consist of invited lectures on atmospheric and oceanic observations, atmospheric and oceanic models, and data assimilation-introductory and advanced methods, atmospheric and oceanic applications to large-scale mesoscale flows. The research conference will follow upon the course, Wednesday-Friday, 15-17 March, and consist of invited and contributed presentations, in oral and poster form.

The deadline for abstracts has passed. Details of this conference were published in the August-September 1994 issues of the Bulletin. A preprint volume will be distributed to registrants at the symposium.

For more information contact the Secretary-General, WMO, 41, av. Giuseppe Motta, C.P.no.2300, CH-1211, Geneva 2, Switzerland. (8/94, r10/94, r11/94)

11th Symposium on Boundary Layers and Turbulence, 27-31 March, 1995, Charlotte, NC

The AMS 11th Symposium on Boundary Layers and Turbulence (formerly called Symposia on Turbulence and Diffusion), organized by the AMS Committee on Boundary Layers and Turbulence, will be held 27-31 March 1995 at the Adam's Mark Hotel in Charlotte, North Carolina. The Symposium will be held in conjunction with the AMS Ninth Symposium on Meteorological Observations and Instrumentation.

The symposium will feature both oral and poster presentations. Possible topics include: 1) turbulence in stratified boundary layers; 2) physical and numerical simulations of turbulence; 3) concentration fluctuations; 4) transport and diffusion of contaminants; 5) Lagrangian models of particle diffusion; 6) boundary layer clouds; 7) field experiment techniques; 8) coherent boundary layer structures; 9) new techniques in turbulence analysis such as wavelets and fractals; 10) chaos and nonlinear dynamics in turbulence; 11) coupled oceanic and atmospheric boundary layers; and 12) turbulence over complex terrain.

The deadline for abstracts has passed. AMS will provide instructions to authors of accepted abstracts. Complete camera-ready manuscripts (up to 4 pages in length), including photos and diagrams, must be submitted to AMS headquarters no later than 1 December 1994. Page charges and additional charges for photo processing will be assessed to defray printing costs. A preprint volume will be distributed at the symposium.

For further information, contact Dr. Edgar Andreas, U. S. Army Cold Regions Research and Engineering Laboratory, 72 Lyme Road, Hanover, NH 03755-1290 (tel: 603-6464436; fax: 603-646-4644). (12/93; r6/94; r10/94; r11/94; r12/ 94)

\section{Ninth Symposium on Meteorological Observations and} Instrumentation, 27-31 March, 1995, Charlotte, NC

The AMS Ninth Symposium on Meteorological Observations and Instrumentation, organized by the AMS Committee on Measurements, will be held 27-31 March 1995, at the Adams Mark Hotel in Charlotte, North Carolina. The symposium will be held in conjunction with the AMS 11th Symposium on Boundary Layers and Turbulence (formerly called Symposia on Turbulence and Diffusion).

The symposium will include both oral and poster sessions. Presenters whose oral and poster submissions are accepted will be required to prepare a camera-ready manuscript that will be published in the symposium proceedings. Provision will be made for vendor exhibits. Presentations were solicited in all aspects of atmospheric measurements (in situ and remote), observations, quality control and assurance, integrated sensor technologies and modeling of sensor performance, network design, and sampling strategies. Both research and operational instrumentation and measurement techniques are welcomed. One area of special emphasis is the outlook for atmospheric soundings (nationally and globally) and the roles of radiosondes, dropwindsondes, commercial aircraft measurements, ground-based and spaceborne remote sensing, and unmanned autonomous vehicles and the associated modeling requirements. All presenters will be encouraged to prepare formal manuscripts shortly after the Symposium for consideration of publication either as an AMS monograph or in a special issue of the Journal of Atmospheric \& Oceanic Technology.

Complete, camera-ready manuscripts (up to 6 pages in length), including photos and diagrams, must be received at AMS headquarters by 15 December 1994. AMS will provide instructions to authors of accepted abstracts. Registrants will receive a preprint volume at the conference. For further information, contact Walter F. Dabberdt, symposium chairperson, NCAR, P. O. Box 3000, Boulder, CO 80307-3000 (fax: 303-497-8770). (4/94; r10/94, r11/94; r12/94)

\section{TOGA 95 Conference, 2-7 April 1995, Melbourne, Aus-} tralia

The sponsors of the WCRP (WMO, ICSU, and IOC), together with SCOR, will hold an international scientific conference to mark the completion of Tropical OceanGlobal Atmosphere (TOGA). The Australian Academy of Science and the Committee of Heads and Marine Agencies will host the conference in Melbourne, Australia, at the Melbourne Hilton, 2-7 April 1995, with the Bureau of Meteorology to act as the lead host agency. AMS is a cooperating organization.

The principal objectives of the conference are 1) to review and evaluate the scientific achievements of TOGA, 2) to determine the extent to which the scientific objectives of TOGA have been achieved, and 3) to discuss future directions emanating from the results of the TOGA program.

The deadline for abstracts has passed. Details of this conference were published in the July-September 1994 issues of the Bulletin. For further information, contact TOGA 95 Conference Secretary, Bureau of Meteorology Research Center, GPO Box 1289K, Melbourne, Vic. 3001, Australia; tel: 6136694046 or 613669 4434; fax: 613669 4660; e-mail: toga95@bom.gov.au (preferred); OMNET: BMRC.AUSTRALIA (optional) or Dr. Peter W. Webster, University of Colorado, PAOS, Boulder, CO 80304, tel: 303492-5882. (7/94, r10/94, r12/94) 
ANS Fifth Topical Meeting on Emergency Preparedness and Response, 18-21 April 1995, Savannah, Georgia

The ANS Fifth Topical Meeting on Emergency Preparedness and Response will be held 18-21 April 1995, at the Radisson Plaza Hotel, Savannah, Georgia. The primary sponsors of this topical meeting are the American Nuclear Society (ANS), the ANS Environmental Sciences Division, and the Savannah River Section of the ANS. This meeting is cosponsored by the U.S. Department of Energy, the U.S. Nuclear Regulatory Commission, the American Meteorological Society, and the Health Physics Society.

The objective of this topical meeting is to provide a broad forum for discussions of recent advances in capabilities for responding to and mitigating the consequences of nuclear, non-nuclear, and natural emergencies.

The deadline for abstracts has passed. A preprint volume containing the extended abstracts will be distributed at the meeting. For further information, please contact Charles $\mathrm{H}$. Hunter, Jr., Technical Program Chairman, Westinghouse Savannah River Company, Building 773-A, Aiken, SC 29805 (tel: 803-725-2953; fax: 803-725-4233). (6/94; r/8/94)

\section{Call for Papers}

\section{1st Conference on Hurricanes and Tropical Meteorol-} ogy, 24-28 April 1995, Miami, FL

The 21st Conference on Hurricanes and Tropical Meteorology, sponsored by the American Meteorological Society, will be held 24-28 April 1995 at the Hyatt Regency Hotel in Miami, FL.

Special sessions are planned on continuing studies from several observational programs, including TOGA COARE, TCM-90 and TCM-92, and TEXMEX.

The deadline for abstracts has passed. AMS will provide instructions to authors of accepted abstracts. Complete, camera-ready manuscripts (page length to be determined at a later date) including photos and diagrams, must be submitted no later than 1 February 1995 to AMS Headquarters. Page charges and any additional charges for photo processing will be assessed to defray printing costs. Registrants will receive a preprint volume at the conference.

The best student paper presented will receive the Max Eaton Award, consisting of a certificate and $\$ 100$. Students or recent graduates should indicate their desire to compete and must be the sole authors of their papers.

For further information, contact Miles Lawrence, conference chairperson, National Hurricane Center, 1320 South Dixie Highway, Coral Gables, FL 33146. (tel: 305-666-4612; fax: 305-536-6881; e-mail: lawrence@nhc.noaa.gov). (8/ 94; r $9 / 94 ; r 10 / 94)$

\section{Call for Papers}

Summer School on Remote Sensing of Processes Governing Energy and Water Cycles in the Climate System, 1-12 May 1995, Plon, Germany

This NATO-Advanced Study Institute (ASI) will cover all aspects and wavelength regions to measure indirectly from satellites, aircraft, or ground the atmospheric and ground properties of processes governing energy and water cycles in the climate system. Three additional lectures will reflect the state-of-the-art in climatology and modelling. All lectures are of basic interest for many climate research issues, in particular for the projects within GEWEX. One day will be spent at a "Remote Sensing Park" with various LIDAR, RADAR, RASS, and passive sounding capabilities. Directors are: E. Raschke, GKSS Research Center Geesthacht; V. V. Salomonson, Earth Sciences Directorate, NASA GSFC; and Y. Fouquart, Lab. Opt. Atm., University Lille.

For more information contact Ralph Nolte-Holube, GKSS Research Center Geesthacht, Institute for Physics P2, P.O. Box 1160, D-21494 Geesthacht, Germany (fax: 494152-872020; e-mail: nolte@ gkss.de). (9/94; r11/94)

\section{Call for Papers}

44th Annual Meeting of the Weather Modification Association, 11-12 May 1995, Tamarron, Colorado

The 44th Annual Meeting of the Weather Modification Association (WMA) will be held 11-12 May 1995 at the Tamarron Meeting and Resort Center located 18 miles from Durango, Colorado and easily accessible form either Denver, Phoenix, or Albuquerque. This meeting is being sponsored by the WMA. The American Meteorological Society is cooperating with this meeting. The WMA was organized to advance understanding about weather modification among operators, scientists, and program managers.

Papers are solicited on those facets of atmospheric research into natural processes which may have relevance to weather modification, including observational and laboratory cloud physics research, scale-interactions, cloud scale organization and evolution, numerical simulations, statistical evaluation, and atmospheric chemistry, in addition to more traditional subjects directly related to experimental and operational weather modification projects. Titles and abstracts were due 1 December 1994. For those authors who wish to have their presentations appear in print, the WMA will provide instruction for the preparation of complete, camera ready manuscripts to appear in a special nonrefereed section of The Journal of Weather Modification. Manuscripts for the non-refereed section must be received no later than 15 February 1995.

Papers are also solicited for the refereed section of The Journal of Weather Modification. The journal accepts papers on all aspects of experimental and operational weather modification projects and research and on basic atmospheric research relevant to weather modification. Manuscripts for review were due 1 December 1994. All submissions should be made to: James Miller, Editor, Institute for Atmospheric Sciences, South Dakota School of Mines and Technology, 501 E. St. Joseph Street, Rapid City, South Dakota, 57701-3995 (tel: 605-394-2293, fax: 605-394-6061). For further information of this meeting contact either James Miller at the above addressor Bob Czys, Atmospheric Sciences Division, Illinois State Water Survey, 2204 Griffith Drive, Champaign, Illinois (tel: 217-333-8496; fax: 217-2440220). (8/94, r12/94) 
WMO International Conference on Meteorological and Hydrological Technology and its Management, 22-26 May 1995, Geneva, Switzerland

The World Meteorological Organization (WMO), in collaboration with other intergovernmental organizations and the private sector, will convene the WMO International Conference on Meteorological and Hydrological Technology and its Management (METEOHYTEC 21) in Geneva, Switzerland, 22-26 May 1995. The AMS is a cooperating organization. The conference is intended to provide a platform for high-level decision-makers from ministries, meteorological and hydrological services, academia, and industry to address new technologies and systems management issues. Experts with senior level experience in the design, acquisition, implementation, and management of new technologies will be the primary speakers.

The deadline for abstracts has passed. Details of this conference were published in the June-August issues of the Bulletin. For further information, please contact the WMO, World Weather Watch, Case postale $2300, \mathrm{CH}-1211 \mathrm{Ge}-$ neva, Switzerland (tel: 41-22-730.82.44; fax: 41-22734.23.26; telex: 41-41-99 OMM CH). (6/94; r8/94; r10/94)

International Global Energy and Water Cycle Experiment (GEWEX) Workshop on Cold-Season/Region Hydrometeorology, 22-26 May 1995, Banff, Alberta, Canada

The International GEWEX Workshop on Cold-Season/ Region Hydrometeorology will be held 22-26 May 1995 in Banff, Alberta, Canada. The workshop will be held in conjunction with the Annual General Meeting of the Candian Geophysical Union (CGU). The major workshop sponsors include the International and Canadian GEWEX project offices, NOAA, the National Weather Service, and the Canadian Atmospheric Environment Service. The AMS is a cooperating organization.

Oral presentations and poster sessions are planned. Extended abstracts were due 1 December 1994 to Terry Krauss, National Hydrology Research Institute, 11 Innovation Blvd., Saskatoon, SK, Canada S7N 3H5 (tel: 306-9754215). Authors will be notified of acceptance of their papers by mid-January 1995 .

The papers presented at the GEWEX workshop will be published as part of the International GEWEX Project Office (IGPO) Document Series. This document will provide guidance and inputs to the different projects in the GEWEX Program, especially the GEWEX Continental-Scale International Project (GCIP) in its focused studies of the Upper Mississippi River basin in 1996-97.

For further information, you may contact Dr. Carroll, Chairman, National Operational Hydrologic Remote Sensing Center, Office of Hydrology, National Weather Service, NOAA, 6301-34th Avenue South, Room 112, Minneapolis, MN 55450-2985 (tel: 612-725-3039; fax: 612-725-3338; Internet: tcarroll@snow.nohrsc.nws.gov). (10/94, r12/94)

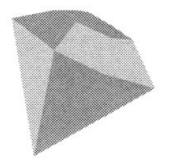

\section{Call for Papers}

The 29th Annual Congress of the Canadian Meteorological and Oceanographic Society, 29 May-2 June 1995, Kelowna, British Columbia, Canada

The 29th Annual Congress of the Canadian Meteorological and Oceanographic Society (CMOS) will be held at Okanagan University College, Kelowna, British Columbia, Canada, from 29 May-2 June, 1995. The Canadian Society of Agrometeorology (CSAM) and the Panel on Energy Research and Development (PERD) are planning to hold their meetings concurrently with this CMOS Congress. The American Meteorological Society is a cooperating organization.

Oral and poster papers, and commercial exhibits in all areas of meteorology, oceanography, and limnology are invited. The Congress will feature special theme sessions on: Environmental Services; Clients, Innovation and Commercialization (congress theme); Air Quality; Atmospheric and Oceanic Processes in the Arctic; Climate and Climate Change; and Physical and Chemical Processes in Lakes.

Abstracts of papers must be received by Dr. W. Hsieh, Chairman of the Scientific Program Committee, by 31 January 1995. Authors are strongly urged to submit abstracts electronically by email. Guidelines for sending an electronic abstract can be obtained automatically by sending a (blank) email message to cmos_form@ocgy.ubc.ca or by anonymous ftp to ogopogo.ocgy.ubc.ca, directory/cmos/abstracts, file "form". If email is not available, please contact W. Hsieh for information on submitting abstracts by other means.

For further information on the scientific program, contact: Dr. William Hsieh, Chairman, Scientific Program Committee, Dept. of Oceanography, University of British Columbia, 6270 University Boulevard, Vancouver, B.C., Canada V6T 1Z4, tel: (604)822-2821; fax: (604) 822-6091; internet: cmos@ocgy.ubc.ca (10/94)

\section{Tenth Conference on Atmospheric and Oceanic Waves} and Stability, 5-9 June 1995, Big Sky, Montana

Tenth Conference on Atmospheric and Oceanic Waves and Stability, sponsored by the American Meteorological Society and organized by the AMS Committee on Atmospheric and Oceanic Waves and Stability, will be held 5-9 June 1995 at the Big Sky Resort, in Big Sky, Montana.

Papers are being solicited in all areas relevant to the application of the methods of wave propagation and stability to the atmosphere and ocean. Particular emphasis will be given to papers related to: 1) planetary scale waves and stability in the atmosphere and ocean with particular attention to their interactions with higher frequency and smaller scale phenomena, 2) synoptic and frontal scale waves and stability in the atmosphere and ocean with particular attention to their mixing properties and the influence of phase changes on such motions, 3 ) convective scale motions in the atmosphere and ocean with particular emphasis on the role of such instabilities in planetary scale circulations in the ocean and atmosphere and their scale interactions, 4) nongeostrophic waves and stability with particular emphasis on inertia-gravity waves and stability, slantwise convection and the interactions of unbalanced flows with balanced motions, 
5) nonlinear stability and turbulence with particular emphasis on predictability and non-modal growth, coherent structures and bifurcation analysis; and 6) laboratory experiments of waves and geophysical instabilities with particular emphasis on the role of physical experiments in strengthening the link between theories and observations of the atmosphere and ocean.

The deadline for abstracts has passed. AMS will provide instructions to authors of accepted abstracts. Complete, camera-ready manuscripts (page length to be determined at a later date) including photos and diagrams, must be submitted no later than 15 February 1995 to AMS Headquarters. Page charges and any additional charges for photo processing will be assessed to defray printing costs. Registrants will receive a preprint volume at the conference.

For further information please contact Dr. Joseph J. Tribbia, program chairperson, CAOWS, NCAR, Box 3000 , Boulder, CO 80307, tel: 303-497-1377, fax: 303-497-1700, email: tribbia@ncar.ucar.edu. (7/94)

The Pacific Science Association (PSA) 18th CongressSymposium on Global Climate and Environment Change: Conference on Asia-Pacific Monsoon Meteorology, and Conference on Impacts of Climate Change on Agriculture Production in the Pacific Rim, 5-12 June 1995, Beijing, China

The Pacific Science Association (PSA) will hold its 18th Quadrennial Congress in Beijing, China during 5-12 June 1995. The Congress will include six symposia and a number of scientific conferences and workshops, with the main theme to be "Population, Resources, and Environments: Prospects and Initiatives." One of the six symposia will be on Global Climate and Environment Change. In addition, the PSA Scientific Committee on Meteorology and Atmospheric Sciences plan to sponsor the Conference on Asia-Pacific Monsoon Meteorology, and the Conference on Impacts of Climate Change on Agriculture Production in the Pacific Rim.

The second circular and other information of the Congress will be available from Prof. Fu Congbin, Secretariat, PSA XVIII Congress, c/o Institute of Atmospheric Physics, Chinese Academy of Sciences, P.O. Box 2718, Beijing 100080, People's Republic of China. Scientists in North America may also contact Prof. C.-P. Chang, Executive Secretary, PSA Scientific Committee on Meteorology and Atmospheric Sciences, Code MR/CP, Dept. of Meteorology, Naval Postgraduate School, Monterey, CA 93943 (tel: 408656-2840; fax: 408-656-3061). (12/93; r4/94)

\section{Call for Papers}

Second Workshop on Nonstationary Random Processes and Their Applications, 11-14 June 1995, San Diego, California

The Second Workshop on Nonstationary Random Processes and Their Applications, will be held 11-14 June 1995. The Workshop is sponsored by NASA Langley Research Center and the Naval Surface Warfare Center. The American Meteorological Society is a cooperating organization.
The theme of this workshop is all aspects of nonstationary signal analysis. In particular, analyses based on wavelets, computer simulations of nonstationary signals, the link between nonstationary and nonlinearity, fractals, and chaos are appropriate subjects for the workshop. Thus, this meeting should provide an opportunity for scientists, mathematicians, and engineers working in this genuinely multidisciplinary field to present state-of-the-art research, to exchange ideas, to address current problems, and to outline future needs and prospects. Confirmed invited speakers include Larry Mahrt (Oregon State University), Chad Spooner (Mission Research Corp.), and Gil Strang (MIT). The abstract deadline is 1 February 1995 . For more information on the meeting or for instructions on how to prepare abstracts, contact Dr. George Trevino, P.O. Box 207, Houghton, MI 49931 (tel: 906-482-9327). (12/94)

\section{Call for Papers}

Fifth International Conference on Precipitation: SpaceTime Variability and Dynamics, 14-16 June 1995, Crete, Greece

The Fifth International Conference on Precipitation will be held in Crete, Greece, 14-16 June 1995. Following the tradition of the previous four conferences this meeting aims at fostering interdisciplinary interaction between meteorologists, hydrologists, mathematicians and statisticians. The central theme of the conference will be research issues related to the problem of linking stochastic and dynamic descriptions of rainfall for the purpose of modeling, estimation, and forecasting. Papers are invited on the following topics: a) precipitation dynamics, b) space-time variability and statistical characterization, c) linkages between dynamics and stochastic descriptions; and d) applications of physical and/or statistical theories in the development of rainfall estimation/ retrieval algorithms.

The deadline for submission of abstracts is 15 December 1994. Partial travel support to selected participants will be provided upon request and subject to availability of funds. Priority will be given to young scientists and graduate students presenting papers. If you would like to be on the mailing list or would like more information on this conference, please contact either one of the organizers: Prof. Efi Foufoula-Georgiou, St. Anthony Falls Hydraulic Lab., Mississippi River and 3rd Ave. SE., University of Minnesota, Minneapolis, MN 55414, tel: 612-627-4595, fax: 612-6274609, e-mail: efi@mykonos. safhl.umn.edu or Prof. A. A. Tsonis, Dept. of Geosciences, Univ. of Milwaukee, P.O. Box 413, Milwaukee, WI 53201, tel: 414-229-5373, fax: 612-2295452, e-mail: aatsonis@csd4.csd.uwm.edu. (7/94)

\section{Call for Papers}

The 1995 Annual Meeting of the American Society of Agricultural Engineers, 18-23 June 1995, Chicago, IL

The 1995 Annual Meeting of the American Society of Agricultural Engineers will be held 18-23 June 1995 in Chicago, IL. A one day session on Applications of the NEXRAD Weather Radar System in Agriculture will be held at this meeting. 
The session will explore applications of NEXRAD in agricultural situations. Papers are being solicited on the following topics: NEXRAD rainfall estimation for small watershed hydrology; interfacing GIS to NEXRAD information; soil moisture estimation from NEXRAD information; insect and bird migration; dust and air pollution monitoring; inversion and light wind monitoring; and other topics closely related. Invited papers describing the NEXRAD System, etc., are planned. The deadline for abstracts is 10 January 1995.

For further information contact, Dr. Mary Lee Wolfe, VPI \& SU, Biological Systems Engineering Department, Seitz Hall, Blacksburg, VA 24061-0303 (tel: 703-231-6092; fax: 703-231-3199; internet: mlwolfe@vtvml.cc.vt.edu). General information may also be obtained from Dr. Dale Linvill, Agricultural Weather Office, 230 McAdams Hall, Clemson University, Clemson, SC 29634-0357 (tel: 803-656-4070; fax: 803-656-0338; internet: CLIMATE@CLEMSON). (10/ 94)

\section{Call for Papers}

Sixth International Meeting on Statistical Climatology, 19-23 June 1995, Galway, Ireland

The Sixth International Meeting on Statistical Climatology (6IMSC) will be held 19-23 June 1995 in Galway, Ireland. The IMSC series of meetings is organized under the aegis of the Steering Committee for International Meetings on Statistical Climatology, currently chaired by Dr. Francis W. Zwiers of the Atmospheric Environment Service (Canada). It is anticipated that 6IMSC will be cosponsored by several organizations, including the American Meteorological Society.

The principal themes of the meeting will be climate variability on all time scales, and climate prediction on time scales of one week to one year. It is intended to hold special sessions at the meeting on ENSO forecasting, climate change detection, ensemble forecasting, extreme value analysis, and spatial statistics. The deadline for abstracts is 16 December 1994. For further information contact the program chairperson, Professor lognaid O'Muircheartaigh, Department of Mathematics, University College, Galway, Ireland (tel: 353-91-75-0389; fax: 353-91-25-700; e-mail: 0001607s@ bodkin.ucg.ie). (1/94; 6/94)

The 48th Canadian Water Resources Association Conference, 20-23 June 1995, Fredericton, N.B., Canada

The 48th Canadian Water Resources Association Conference will be held in Fredericton, N.B., Canada 20-23 June 1995. The theme of the conference will be "Managing the Water Environment: Hard Decisions from Soft Data." The American Meteorological Society is a cooperating organization. Concurrent sessions will also be held for the following groups: CANCID, contact Laurie Tollefson (tel: 306-867-9951); CSHS, contact Ivan Lorant (tel: 416-2294646; IWRA, contact Jim Kirch (tel: 819-997-7489). For further information on the conference, please contact Nabil Elhadi, Environment Planning and Sciences Branch, N.B. Environment, P. O. Box 6000, Fredericton, N.B., E3B 5H1 Canada (tel: 506-457-4844; fax: 506-453-2390). (9/94)

\section{Call for Papers}

International Symposium on Environment and Biometeorology, 20-22 July 1995, Beijing, China

The International Symposium on Environment and Biometeorology will be held at Zhongyuan Hotel, Beijing, China, 20-22 July 1995. The symposium is sponsored by the International Society of Biometeorology, the Institute of Agrometeorology, Chinese Academy of Agricultural Sciences, the Institute of Occupational Medicine, and the Chinese Academy of Preventative Medicine. The American Meteorological Society is a cooperating organization.

Papers are solicited on issues of humans, animals, plants, microorganisms, nutrition, and toxicology in relation to climate and climate change. Climate and climate change with respect to sustainable agriculture and forestry; biodiversity; desertification, gas and energy exchanges, bio-geochemical fluxes; UV radiation, ozone, and atmospheric electric parameters; urban meteorology; and indoor air quality are within the scope of the symposium.

Contributors of papers are requested to send a 300word abstract no later than 15 January 1995, to Ping Qian, Institute of Agrometeorology, CAAS, 30 Baishiqiao Road, Beijing 100081, China (fax: 861831 6545). For further information, you may also contact N. N. Barthakur, McGill University (tel: 514-398-7938; fax: 514-398-7990). (9/94)

\section{Call for Papers}

Third International Symposium on Air-Water Gas Transfer, 24-27 July 1995, Heidelberg, Germany

The Third International Symposium on Air-Water Gas Transfer, will be held at the University of Heidelberg, Hedelberg, Germany, 24-27 July 1995.

This symposium is the third in a sequence of symposia on air/water gas transfer. The organizers feel that the increased interest in gas transfer as well as the current and expected progress in experimental techniques and theoretical understanding makes a third symposium in 1995 a very valuable event.

The third symposium will focus on a deeper understanding of gas transfer in natural systems: air-sea gas transfer and reaeration of rivers and lakes. Papers are called for the following subjects: 1) physical and chemical mechanisms, 2) modeling biogeochemical cycles, 3) remote sensing, 4) innovative measuring technology, 5) laboratory measurement, and 6) field measurements.

Interested persons should submit a two-three page extended abstract by 20 January 1995. Authors of accepted papers will be notified by 10 March 1995; the deadline for submission of the finished camera-ready paper is $\mathbf{2 4}$ July 1995. For further information contact: Edward C. Monahan, Director, Connecticut Sea Grant College Program, University of Connecticut MSI, 1084 Shennecossett Rd., Groton, CT 06340-6097. (9/94)

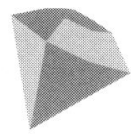




\section{Call for Papers}

Seventh Conference on Mountain Meteorology, August 1995, Breckenridge, CO

The Seventh Conference on Mountain Meteorology, sponsored by the American Meteorological Society will be held August 1995 in Breckenridge, Colorado.

The mountain meteorology conference has established a tradition of providing an interdisciplinary forum on the effects of mountains and complex terrain on the atmosphere. Papers are solicited in all areas of mountain meteorology including the role of mountains in climate and the general circulation, lee cyclogenesis, terrain-induced waves and instabilities, downslope windstorms and mesolow formation, orographic clouds and precipitation, mountain-valley circulations, slope winds, topographically trapped disturbances including those over large-scale orography as well as in the vicinity of coastal and/or steep topography, radiation and energy budgets over complex terrain including their parameterizaton in regional and global models, and the development of numerical modeling methods applicable specifically to complex terrain.

A special session is planned on the effect of complex terrain on air quality at scales ranging from local mountainvalley systems to regional domains encompassing multiple pollution sources (this session will serve as a prospectus for a potential short-course to be organized jointly with AMS Committee on the Meteorological Aspects of Air Pollution).

Two copies of a single page abstract, including the corresponding author's address, phone number and fax numbers, and e-mail address should be sent by mail or electronically no later than 24 January 1995 to Dr. William D. Neff, NOAA/ETL, Attn: R/E/ET7, 325 Broadway, Boulder, CO, 80303-3328, tel: 303-497-6265, fax: 303-497-6101 or 303-497-6978; e-mail: wneff@ etl.noaa.gov). Authors should indicate whether the paper is submitted for oral presentation or for a poster session. Notification of acceptance will be made by 21 February 1995.

Complete camera-ready manuscripts (page length to be determined at a later date), including photos and diagrams, must be received at AMS headquarters by 17 April 1995. AMS will provide instructions to authors of accepted abstracts. Registrants will receive a preprint volume at the conference.

For further information, contact the program cochairs, William D. Neff at the above address or Teddie Keller, NCAR, P.O. Box 3000, Boulder, CO 80307-3000, tel: 303-4978428, fax: 303-497-8401, e-mail: tkeller@ ncar.ucar.edu). $(10 / 94)$

Third Thematic Conference on Remote Sensing for Marine and Coastal Environments, 18-22 September 1995, Seattle, WA

The Third Thematic Conference on Remote Sensing for Marine and Coastal Environments will be held 18-22 September 1995 at the Westin Hotel in the heart of downtown Seattle. The American Meteorological Society is a cooperating organization.

This conference will focus on applying remote sensing technologies and geographic information systems (GIS) to solve real-world problems in marine and coastal environments. Technical sessions will include: 1) Oil Spills and Natural Disasters, 2) Ocean Surface Current Measurements, 3) Natural Resources Management, 4) Water Quality, 5) Coastal Environmental Monitoring, 6) Coastal Mapping and Charting, 7) Satellite Oceanography, 8) Data Integration and Interpretation, and 9) New Sensors and Systems.

This conference program will include plenary sessions, interactive poster presentations, exhibits program, awards program, hands-on workshops, student and guest programs, and on-site employment services.

For further information contact: ERIM Conferences, P.O. Box 134001, Ann Arbor, Ml 48113-4001 (tel: 313-9941200, ext. 3453, fax: 313-994-5123). (9/94)

\section{Second European Conference on Applications of Me-} teorology, 25-29 September 1995, Toulouse, France

After the success of the First European Conference on Applications of Meteorology, which was held in Oxford, from 27 September to 1 October 1993, it has been decided to hold such events on a regular basis. At the invitation of Meteo France, the Second European Conference on Applications of Meteorology will be held in the Centre International de Conference of Meteo-France in Toulouse from 25-29 September 1995. The American Meteorological Society is a cooperating organization.

The conference will provide a forum for exchange of information on european activities in the development of forecasting practice and the applications of meteorology for both public and commercial services. A special emphasis will be put on operational weather forecasting. This will lead to closer collaboration between organizations within Europe. The conference will enhance dialogue between European National Meteorological Services and with government agencies, academia, and the private sector.

An attendance of some 200-300 people is envisioned, drawn from all organizations, private or public, active in meteorology. It is hoped that many professional forecasters will take part. An official "call for papers" will follow. For further information, contact Francois Duvernet, MeteoFrance, 1 Quai Branly, 75400 Paris Cedex 07, France (tel: 331455670 23; fax: 331455670 05). (9/94)

\section{Call for Papers}

\section{7th Conference on Radar Meteorology, 9-13 October 1995, Vail, Colorado}

The 27th Conference on Radar Meteorology, sponsored by the American Meteorological Society, will be held 9-13 October 1995 in Vail, Colorado. On the weekend prior to the conference, various facilities in the Fort Collins-Boulder area, including the CSU-CHILL radar and the NOAA network profiler, will host open houses for conference attendees. Details will be provided in future notices.

Papers on all aspects of radar meteorology are invited. Special emphasis is being placed on applications of NEXRAD technology, TOGA COARE studies using shipboard and airborne Doppler radars, spaceborne radar, the use of profiler networks, the technology and applications of cloud 
radars, radar meteorology education, and radar analysis and display software.

Both oral and poster presentations are invited. Oral presentations of approximately 10 minutes in length are planned. Authors should state if they prefer poster presentations, otherwise the program committee will assume an oral presentation is being requested. The program committee will make the final decision as to which presentations will be oral and which will be posters. Some parallel sessions are planned. Because we anticipate a large number of abstracts, submission of more than one paper by the same lead author is strongly discouraged. We also discourage multiple oral presentations by the same speaker. The conference will feature several invited keynote speakers and will also have topics that could be the focus of small, informal discussions which we would like to promote at the conference.

Titles and abstracts (not to exceed one page) should be received no later than 15 February 1995. Please send your abstracts to Prof. Steven A. Rutledge, Program Chair, Department of Atmospheric Science, Colorado State University, Fort Collins, CO 80523 (tel: 303-491-8283 or 303-491-8680; fax: 303-491-8449). Inquires may be directed to the program chair via e-mail: rutledge@olympic.atmos.colostate.edu. However, abstracts must be submitted by regular mail or fax. Authors must include the following information on their abstract: names and affiliations of all authors, the mailing address, telephone and fax numbers, and e-mail (if available) of the corresponding author. Authors will be notified by 1 April 1995 on the status of their abstract.

Complete camera-ready manuscripts (page length to be determined at a later date), including photos and diagrams, must be received at AMS headquarters by 15 May 1995. AMS will provide instructions to authors of accepted abstracts. Registrants will receive a preprint volume at the conference.

At the 27th conference, the first Spiros G. Geotis Prize will be awarded for the best student paper. The prize, consisting of an inscribed book and a plaque, is in memory of Spiros Geotis, who in his university career of more than 40 years inspired many students. Students who wish to be considered for the prize should so indicate when submitting their abstracts and must be lead authors. Graduates who completed their degree requirements since the 26th radar conference (May 1993) are also eligible for the Geotis Prize. Papers must be based on work done by a student or largely completed while a student in the case of recent graduates. Papers will be judged on scientific content and presentation.

For further information contact Prof. Steven A. Rutledge at the above address. (10/94)

\section{6th AMS Annual Meeting}

\section{January-2 February 1996, Atlanta, Georgia}

The 76th AMS Annual Meeting will be held 28 January2 February 1996 at the Atlanta Marriott Marquis in Atlanta, Georgia. Several conferences, a large commercial exhibit, a combined book exhibit, and a conference awards banquet are being planned. "Calendar of Meetings" includes a listing of those conferences presently being scheduled.
The theme of the 76th AMS Annual Meeting will encompass three expanded elements of AMS community activities. The first is education. Both continuing and precollege education are receiving broader attention. The AMS Project ATMOSPHERE initiative for enhancing $\mathrm{K}-12$ education has gained national recognition. These types of educational activities will benefit by even greater involvement of our scientific community. The second element is the applications of meteorology to environmental and other needs of society. The numerous contributions of the private meteorological sector to these areas deserve recognition especially now when the importance of scientific applications to the problems of the world is so widely recognized. Job market opportunities for meteorologists and oceanographers in the applications area are expanding and this must be made more visible. The third element is physical oceanography. On the 25th anniversary of the Journal of Physical Oceanography it is most appropriate to note the growing collaboration between oceanographers and meteorologists to address important scientific problems of climate and the environment. (12/94)

\section{Call for Papers}

22nd Conference on Agricultural and Forest Meteorology, 28 January-2 February 1996, Atlanta, Georgia

The 22nd Conference on Agricultural and Forest Meteorology, 28 January-2 February 1996, will be held as part of the 76th AMS Annual Meeting at the Atlanta Marriott Marquis, Atlanta, Georgia. A joint session is planned with the 12th Conference on Biometeorology and Aerobiology.

One of the themes of the 1996 Annual Meeting is the role of meteorology in addressing major issues such as the environment. Papers are solicited which highlight applied agricultural and forest meteorology programs and their efforts to address environmental issues. Papers are also solicited on environmental monitoring networks, use of new technology, and information dissemination.

A second theme of the 1996 Annual Meeting is education. The number of programs specializing in the education of meteorologists in the fields of agriculture and forestry have declined in recent years. A special session will be devoted to discussing the education of agricultural and forestry meteorologists.

Special workshops are being considered, including one on how to take advantage of the Internet in obtaining weather data, forecasts, and other information and on using the Internet for dissemination.

Posters are strongly encouraged. Posters on all topics are solicited, especially those which report on preliminary research results, instrumentation, and emerging technologies.

Papers on all aspects of agricultural and forecast meteorology are solicited. Sessions will be organized based on the papers submitted. Titles and one-page abstracts should be sent by 1 June 1995 to the Program Chairperson: Dr. Paul Heinemann, Department of Agricultural and Biological Engineering, Penn State University, University Park, PA 16802 (tel: 814-865-2633; fax: 814-863-1031; E-mail: hzh@psu.edu. Please indicate if the abstract if for a paper or poster and include speaker's complete mailing and e-mail 
addresses, plus telephone and fax numbers. Abstracts are encouraged to be sent to the program chairperson via e-mail if possible.

Authors of accepted papers will be notified by 1 July 1995. Early submission of abstracts will allow earlier acceptance of papers and posters. AMS will provide instructions to authors of accepted abstracts. Complete, camera-ready manuscripts (page length to be determined at a later date) including photos and diagrams, must be submitted no later than 1 September 1995 to AMS Headquarters. Page charges and any additional charges for photo processing will be assessed to defray printing costs. Registrants will receive a preprint volume at the conference.

For further information on the conference, contact the committee chairperson: Rodger R. Getz, NWS SE Agricultural Weather Service Center, P.O. Box 3267, Auburn, AL 36831-3267 (tel: 205-844-4514; fax: 205-844-5933 [Note: area code changes to 334 on 1 January 1995]; e-mail: rgetz@awis.auburn.edu). (12/94)

\section{Call for Papers}

12th International Conference on Interactive Information and Processing Systems (IIPS) for Meteorology, Oceanography, and Hydrology, 28 January-2 February 1996, Atlanta, Georgia

The 12th International Conference on IIPS, sponsored by AMS, will be held as part of the 76th AMS Annual Meeting. The meeting will be cosponsored by the World Meteorological Organization (WMO), the Joint Oceanographic Institutions (JOI), the American Water Resources Association (AWRA), and the Association of American Geographers (AAG).

This applied interactive technology conference brings together the government and private sectors, both international and national, and those who supply or use data and information systems and technology.

The conference will include exhibits and demonstrations which continue to be popular and help to illustrate the practicality of using off-the-shelf, demonstrated marketable systems and software tailored to meet the needs of meteorology, oceanography, and hydrology. Potential exhibitors should contact Yale Schiffman, Exhibits Manager, American Meteorological Society, $1701 \mathrm{~K}$ Street, NW, Suite 300, Washington, DC 20006 (tel: 202-466-6070; fax: 202-4666073).

Features at the past 1995 11th IIPS Conference, such as tutorials and electronic posters in which individuals are able to demonstrate their results on a one-to-one basis, along with related papers on High Performance Computing Systems, Geographic Information Systems (GIS), NASA's Earth Observing System (EOS), Multi-Media Information Systems, Educational Information Systems, and Advanced Human Computer Interaction Systems, are encouraged for the 12th IIPS Conference as well.

Sessions tentatively planned include U.S. National Systems-Present and Future; IIPS in Europe and in the Pacific Rim, Visualization, and Human Factors; Data Access, Networks and Management; National Weather Service Modernization Program; NEONS; EOS; Artificial Intelligence and High Performance Computing; Training, Education, and Laboratory Systems; Interactive Systems in Climatology and Atmospheric and Oceanographic Sciences; and Interactive Systems in Operational Meteorology. We are also planning a joint session with the Fifth Symposium on Education, "Education for the Atmospheric and Oceanographic Sciences: Building the Future on a Solid Foundation" and another special session on the NOAA satellite programs.

PC and compatibles, PS/2 and Macintosh personal computers will be provided for the electronic posters, and presenters are encouraged to use them. Portables provided by presenters are welcome. Large-screen video projection for on-line, computer-driven color (RGB) digital systems with resolutions of $640 \times 512$ and $1280 \times 1024$ will be provided for presentations. Use of SUN Microsystems SPARC workstations, IBM RISC workstations, Super VHS, VHS, and 3/4" U-Matic cassettes for television also is encouraged. Those who wish to use these systems must indicate their intentions in their abstracts. Any questions concerning facilities for electronic posters and other demonstrations should be directed to Yale Schiffman at the above address.

The organizing committee for the 12th IIPS Conference includes: William B. Bendel of Bendel Associates, David Blaskovich of Cray Research, Inc., Horst Bottger of ECMWF, Maureen Cianciolo of TASC, Lawrence Denton of Denton \& Associates, G. Stanley Doore, Donald A. Dueck of AES in Canada, Michael Goldberg of The Mitre Corporation, Kenneth D. Hadeen of NOAA/NCDC, Steve Holt of The Mitre Corporation, Robert E. Introne of TASC, John R. Lincoln of WMO in Geneva, Nancy Lopez of the USGS, Alexander E. MacDonald of NOAA/ERL, Donald Mock of NOAAERL, William R. Moninger of NOAAERL, Anthony Mostek of NOAANMC, Patricia M. Pauley of the Naval Post Graduate School, James A. Schiavone of AT\&T Bell Laboratories, J. K. Daniel Soderman, ICSC — World Laboratory.

Abstracts must be submitted by 1 June 1995 to the Conference Chairperson, Dr. Robert F. Brammer, 55 Walkers Brook Drive, Reading, MA 01867 (tel: 617-942-2000; fax: 617-942-7100). AMS will provide instructions to authors of accepted abstracts. Complete, camera-ready manuscripts (page length to be determined at a later date) including photos and diagrams, must be submitted no later than 1 September 1995 to AMS Headquarters. Page charges and any additional charges for photo processing will be assessed to defray printing costs. Registrants will receive a preprint volume at the conference.

For further information, contact Dr. Robert F. Brammer at the above address and telephone number. (12/94)

\section{Preliminary Announcement}

12th Conference on Biometeorology and Aerobiology, 28 January-2 February 1996, Atlanta, Georgia

The 12th Conference on Biometeorology and Aerobiology, sponsored by the American Meteorological Society, will be held 28 January-2 February 1996 as part of the 76th AMS Annual Meeting at the Atlanta Marriott Marquis, Atlanta, Georgia. A joint session is being planned with the 
22nd Conference on Agricultural and Forest Meteorology. A "call for papers" will be published in the January issue of the Bulletin.

For further information, contact Bertrand Tanner, Campbell Scientific, Inc., P.O. Box 551, Logan, UT 84321 (tel: 801-753-2342; fax: 801-752-3268). (12/94)

\section{Call for Papers}

Ninth Joint Conference on the Applications of Air Pollution Meteorology with the Air and Waste Management Association, 28 January-2 February 1996, Atlanta, GA

The Ninth Joint Conference on the Applications of Air Pollution Meteorology with the Air and Waste Management Association, organized by the AMS Committee on Meteorological Aspects of Air Pollution (CMAAP), will be held 28 January-2 February 1996, at the Atlanta Marriott Marquis in Atlanta, Georgia, as a part of the 76th AMS Annual Meeting. The meeting will be cosponsored by the Air Quality Committee (AB3) of the Air and Waste Management Association.

Both poster and oral presentations will be solicited in all areas of air pollution meteorology. It is expected that sessions will be held covering: 1) the dispersion environment; 2) meteorology in emissions determinations; 3) long-range and mesoscale pollutant transport and fate; 4) meteorology and photochemistry; 5) advanced dispersion models and modeling systems; 6) topics in model evaluation; 7) complex flows affecting dispersion near structures and urban environments; 8) coastal and complex terrain issues; and 9) meteorology and air toxics issues. Special emphasis will be given to new developments in the above areas.

Abstracts will be required by 1 June 1995. Details concerning format and page charges will be provided to authors of accepted presentations. Following acceptance, manuscripts must be submitted to AMS Headquarters by 1 September 1995. For further information, contact Ronald L. Petersen, CPP, Inc., 1415 Blue Spruce Drive, Ft. Collins, CO 80524 (tel: 303-221-3371; fax: 303-221-3124). (9/94)

\section{Preliminary Announcement}

Eighth Conference on Satellite Meteorology and Oceanography, 28 January-2 February 1996, Atlanta, Georgia

The Eighth Conference on Satellite Meteorology and Oceanography will be held 28 January-2 February 1996, as part of the 76th AMS Annual Meeting at the Atlanta Marriott Marquis, Atlanta, Georgia. The conference is organized by the AMS committee on Satellite Meteorology and Oceanography (CSMO). The conference is being held at this time to support the 25th anniversary of physical oceanography, the Society's efforts in expanding its commitment to meteorological education, and to encourage the application of remote sensing to environmental problems, all of which are themes of the AMS 76th Annual Meeting.

Both poster and oral presentations will be solicited in a future "call for papers". Special efforts will be taken to make the poster sessions an integral part of the conference. A panel discussion will be held as part of a regular conference session to address a current issue in satellite meteorology.
Also, a pre-conference training course is being planned. Additional information will be provided in a future Bulletin or may be obtained from one of the following Program Chairpersons: Gary J. Jedlovec, NASA/Global Hydrology and Climate Center, 977 Explored Blvd., Huntsville, AL 35806 (internet: Gary.Jedlovec@msfc.nasa.gov); or Grant Petty, Dept. of Earth and Atmospheric Sciences, Purdue University, West Lafayette, IN 47907 (internet: gpetty@ rain.atms.purdue.edu). (12/94)

\section{Call for Papers}

Fifth Symposium on Education, 28 January-2 February, 1996, Atlanta, Georgia

The Fifth Symposium on Education will be held 28 January-2 February, 1996, as a part of the 76th AMS Annual Meeting at the Atlanta Marriott Marquis, Atlanta, Georgia. The symposium will be jointly sponsored by the Board on School and Popular Meteorological and Oceanographic Education and the Board on Meteorological and Oceanographic Education in Universities. The theme of the symposium will be "Education for the Atmospheric and Oceanic Sciences: Building the Future on a Solid Foundation." Papers on all facets of $\mathrm{K}-12$ and college/university undergraduate and graduate education are invited. At the $\mathrm{K}-12$ level, there will be special emphasis on Project ATMOSPHERE as it enters its fifth year of operation, the Maury Project, and other precollege educational outreach programs by the atmospheric and oceanographic communities. In addition, papers or posters are requested on initiatives to promote popular education and general awareness of weather, climate and ocean topics and their impact on societal issues. At the college/university level, the focus will be on meeting curricular needs for both general and professional education in the atmospheric and oceanic sciences. Papers are also requested on efforts to promote continuing education for professionals in the atmospheric and related sciences. There will be a joint session with the 12th International Conference on Interactive Information and Processing Systems (IIPS) for Meteorology, Oceanography, and Hydrology featuring activities that utilize weather and ocean products to promote education and skills needed for the Information Age of the Future.

Titles and abstracts should be sent to the conference cochairpersons, at the address below by 1 June 1995 . Please provide complete mailing and e-mail addresses, plus telephone and fax numbers. Oral, poster, and video presentations are planned. Authors of accepted papers will be notified by 1 August 1995. AMS will provide instructions to authors of accepted abstracts. Complete, camera-ready manuscripts (page length to be determined at a later date) including photos and diagrams, must be submitted no later than 1 September 1995 to AMS Headquarters. Page charges and any additional charges for photo processing will be assessed to defray printing costs. Registrants will receive a preprint volume at the conference.

For further information, contact the Program Cochairpersons: David R. Smith (papers on K-12 topics), Oceanography Department, United States Naval Academy, 572 Holloway Road, Annapolis, MD 21402 (fax: (410) 293- 
2137) or Lisa Bastiaans (college/university topics and joint sessions with IIPS), Nassau Community College, Physical Sciences Department, Garden City, NY 11530 (fax: (516)5727846). (12/94)

\section{Call for Papers}

Conference on Coastal Oceanic and Atmospheric Prediction, 28 January-2 February, 1996, Atlanta, Georgia

The Conference on Coastal Oceanic and Atmospheric Prediction will be held 28 January-2 February 1996 as a part of the AMS 76th Annual Meeting at the Atlanta, Marriott Marquis, Atlanta, Georgia. The conference will be cosponsored by the American Meteorological Society Committees on Meteorology and Oceanography of the Coastal Zone and Interaction of the Sea and Atmosphere.

The purpose of this meeting is to strengthen the scientific and technical communications between physical oceanographers and meteorologists involved in this topic, from research and operational perspectives, at a time when both NOAA (NWS, NOS, and OAR) and the Navy are taking pioneering $R \& D$ and operational steps in the direction of coastal oceanic and atmospheric prediction.

The conference will address, research, development, and operational issues bearing on the prediction of coastal oceanic and atmospheric circulation and weather. Here, "coastal" pertains to the domain $\pm \mathrm{ca}$. $300 \mathrm{~km}$ from the coastline, and "prediction" encompasses simulation as well as hindcasting, nowcasting, and forecasting. Observing, modeling, and data assimilation systems will be addressed. In particular, the utilization of satellite and other remote sensing systems is of interest. Papers on environmental and societal applications, plus value-added industry opportunities, are also solicited.

Titles and one-page abstracts should be sent to the conference Cochairpersons, at the address below by 1 June 1995. Please provide complete mailing and e-mail addresses, plus telephone and fax numbers. Oral, poster, and video presentations are planned. AMS will provide instructions to authors of accepted abstracts. Complete, camera-ready manuscripts (page length to be determined at a later date) including photos and diagrams, must be submitted no later than 1 September 1995 to AMS Headquarters. Page charges and any additional charges for photo processing will be assessed to defray printing costs. Registrants will receive a preprint volume at the conference.

For further information, contact C. H. (Chuck) Wash or Chris Mooers, conference cochairpersons: Dr. Chuck Wash, Department of Meteorology, Naval Postgraduate School, Monterey, CA 93943; Dr. Chris Mooers, Ocean Pollution Research Center, Rosenstiel School of Marine and Atmospheric Science, University of Miami, 4600 Rickenbacker Causeway, Miami, FL 33149-1098 (tel: 305-361-4825; fax: 305-361-4701). (11/94, r12/94)

\section{Index to Advertisers}

$\begin{aligned} \text { c2 } & \text { Alden Electronics } \\ \mathbf{c 4} & \text { Belfort Instrument Company } \\ \mathbf{2 3 2 3} & \text { Vaisala, Inc. Finland } \\ \mathbf{2 3 2 5} & \text { NOAA/NESDIS } \\ \mathbf{2 3 2 7} & \text { University of Colorado } \\ \mathbf{2 3 2 9} & \text { Campbell Scientific, Inc. } \\ \mathbf{2 3 3 1} & \text { Historical Publications } \\ \mathbf{2 3 3 3} & \text { Remtech, Inc. } \\ \mathbf{2 3 3 9} & \text { Climatronics Corporation } \\ \mathbf{2 3 4 1} & \text { Vaisala, Inc. } \\ \mathbf{2 3 4 3} & \text { NOAA/NESDIS } \\ \mathbf{2 3 4 7} & \text { Yankee Environmental Systems, Inc. } \\ \mathbf{2 3 4 9} & \text { Scientific Technology, Inc. } \\ \mathbf{2 3 5 1} & \text { University Corporation for Atmospheric Research } \\ \mathbf{2 3 5 3} & \text { Vaisala, Inc. } \\ \mathbf{2 3 5 4} & \text { University of Washington } \\ \mathbf{2 3 5 5} & \text { Marta Systems, Inc. } \\ \mathbf{2 3 5 7} & \text { MeteoQuest, Inc. }\end{aligned}$

AMS Publications, Preprints, etc.

c3 75th AMS Annual Meeting

2265 AMS Polo Shirts

2268 MGA on CD-ROM

2288 The Representation of Cumulus Convection in Numerical Models

2376 75th AMS Annual Meeting and Exhibition Hotel and Travel

2383 Employment Announcements

2384 26th International Conference on Radar Meteorology

2429 AMS Silk Ties and Scarves

2430 AMS Publications

2431 Table of Contents: Weather and Forecasting

2432 Table of Contents: Journal of Applied Meterology

2433 Table of Contents: Journal of the Atmospheric Sciences

(c) Copyright 1994, American Meteorological Society (AMS). Permission to use figures, tables, and brief excerpts from this journal in scientific and educational work is hereby granted, provided source is acknowledged. Any use of the material in this journal that is considered to be "fair use" under Section 107 or that satisfies the conditions specified in Section 108 of the U.S. Copyright Law (17 USC, as revised by P.L. 94-553) does not require the Society's permission. Items that do not bear their own separate copyright notices either are in the public domain or are U.S. Government works for which copyright protection is not available. Authorization to photocopy items bearing individual AMS copyright notices at the bottom of their first page is granted by the AMS for libraries and other users registered with the Copyright Clearance Center (CCC) Transactional Reporting Service, provided the copies are for internal or personal use, or for the internal or personal use of specific clients, and further provided the base of $\$ 4.25$ per copy $+\$ 0.29$ per page is paid directly to the CCC, 222 Rosewood Drive, Danvers, MA 01923, and that the following fee code for this journal is reported with the payment to CCC: 0003-0007/91 $\$ 4.25+\$ 0.29$. Republication, systematic reproduction, and any other use of any material in this journal, unless exempted by the above statements, requires written permission or license from the AMS. "American Meteorological Society," the Seal of the American Meteorological Society, and the AMS Seal of Approval are registered trademarks of the American Meteorological Society. 


\section{American Meteorological Society}

\section{5th AMS Annual Meeting and Exhibition}
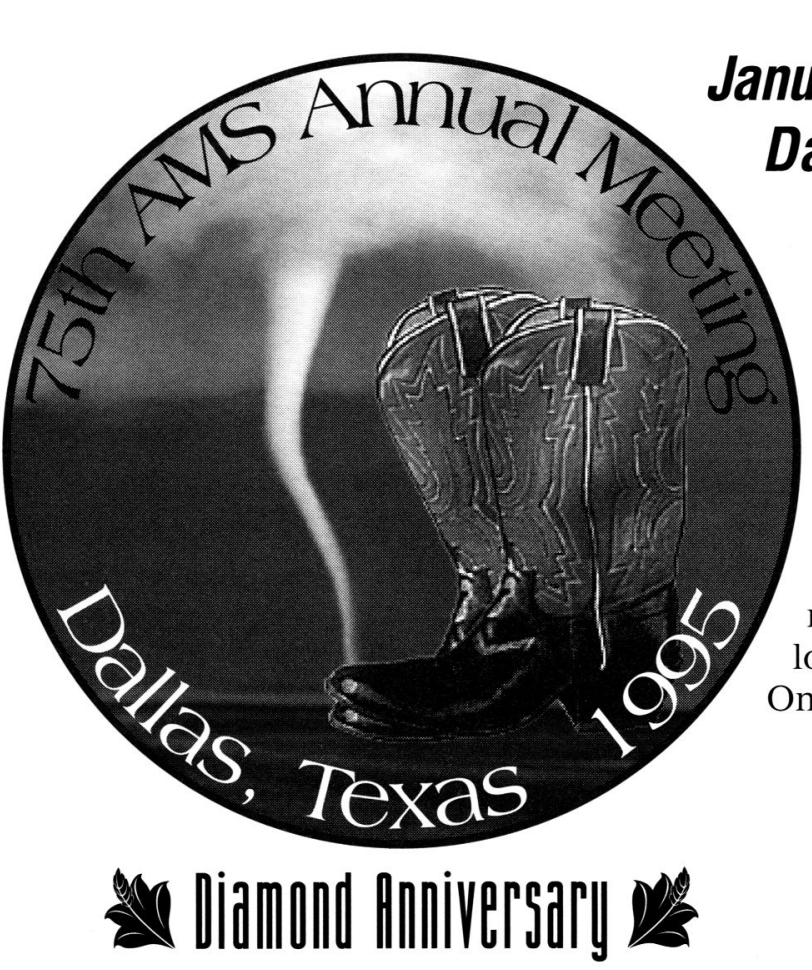

\section{OMEGA WORLD TRAVEL}

Omega World Travel and American Airlines, your official travel partners, offer $5 \%$ discounts off the lowest applicable fare to Dallas and $10 \%$ off the regular economy. To make your reservations with Omega, call at the numbers listed below, or you may call your local Omega office. There are over 220 Omega offices nationwide.

Tel: 800-75-OMEGA or 800-756-6342 In Virginia, call 703-359-8888; fax: 703-359-8887 8:30 A.M. $-5: 30$ P.M. EST, Mon-Fri; 10 A.M.-2 P.M. EST, Sat After hours, call: 800-US-OMEGA Mention AMS when making travel reservations.

\section{LOEWS ANATOLE HOTEL}

Loews Anatole Hotel is pleased to welcome the American Meteorological Society for their "Diamond Jubilee." Time is running out, so make your room reservations now! Rates are as follows:

Single

Double

Call for reservations at 214-761-7500 (fax: 214-761-7808), 7 A.M.-9 P.M. CST, M-F; 8 A.M.-8 P.M. CST, Sat/Sun. All room taxes will be waived for federal government and State of Texas employees upon presentation of a valid government ID card or pay stub and a Texas Sales and Use Tax Exemption Certificate. A copy of the Exemption Certificate will be available at the AMS registration desk. Sales tax on food will be exempt only if the bill is paid directly by the State of Texas or federal government, not out of pocket. Mention AMS when making hotel reservations. 